\title{
Benign Synovial Neoplasm
}

National Cancer Institute

\section{Source}

National Cancer Institute. Benign Synovial Neoplasm. NCI Thesaurus. Code C3829.

A benign neoplasm arising from the synovial membrane. Examples include the diffuse giant cell tumor of tendon sheath and localized giant cell tumor of tendon sheath. 